\title{
化膿性膝性関節炎に対する開放運動療法
}

\author{
生 田 拓 也* 北 村 歳 男* 石 川 純一郎* \\ 島袋孝 尚*原紘 一 ${ }^{*}$
}

\section{Functional Treatment of Pyogenic Arthritis of the Knee}

\begin{abstract}
Takuya Ikuta*, Toshio Kitamura*, Junichiro Ishikawa*,
\end{abstract} Takanao Shimabukuro*, and Koichi Hara*

化膿性膝関節炎に対し関節切開排膿後, 創開放のまま直後より運動療法を行い良好な結果を得ているの で報告した．症例は 25 例 26 膝で，性別は男性 8 例，女性 17 例，年齢は平均 68.0 歳であった。 発症原因 として明らかであった症例は 14 膝で関節内注射 13 膝，針治療 1 膝であった。起因菌が同定された症例は 13 膝で MSSA 8 膝, MRSA 2 膝, ブドウ球菌属 1 膝, 連鎖球菌属 1 膝であった. 全例, 一次的に炎症は 鎮静化し再発を認めていない．創は縫合を追加した 3 例を除き自然閉鎖した．創閉鎖まで要した期間は平 均 29.0 日であった. 本法は他の方法と比較し, 簡便であり治癒率が高く優れた方法であると考えられた. しかしながら，高齢で関節変形が高度な症例にいかにモチベーションを維持させるかという問題点が存在 した.

Twenty six patients with pyogenic arthritis of the knee were treated by open arthrotomy and early passive motion. All patients healed without subsequent operation. Of these patients, five had excellent results, eighteen good results, and four had a fair results according to the modified Ballard's evaluation method.

This is a useful and simple method for treating pyogenic arthritis of the knee.

Key words : pyogenic arthritis (化膿性関節炎), knee (膝), arthrotomy (関節切開術), functional treatment（機能的運動療法）

\section{I.はじめに}

化膿性膝関節炎は治療の時期や方法を誤ると機能障 害を残すことが少なくない. 関節切開排膿後, 創開放 のまま直後より運動療法を行い良好な結果を得たので, 以前に本学会にて報告した。 今回さらに症例を重ねた ので，その結果を報告する.

\section{II. 手 術 方 法}

原則的に腰麻下にて行った. 全身状態が良くない場 合や，診断当日に緊急で手術を行う場合は局麻下に行つ た.

皮切は膝蓋骨の両側に膝蓋骨とほぼ同じ長さに加え, 同部位で retinaculum, 関節包を切開し関節内に達し た. 関節内を充分に洗浄し関節軟骨や滑膜の状態を確
認後, 止血を行い, 創は開放したままガーゼを当てて 弾力包帯で圧迫固定を行った. 滑膜切除は出血のコン トロールが難しくなることもあり，行わなかった（図 1).

\section{III. 術 後 療 法}

術直後より CPM にて可動域訓練を開始し，翌日よ り午前, 午後 1 時間ずつ CPM にて可動域訓練を続け た. 創部からの浸出液が減少する術後 $2 \sim 3$ 週より荷 重を開始した。創部のガーゼは毎日交換し, ESR, CRP が正常化するまで抗生剂投与を静注もしくは経 ロで続けた。
IV. 対
象

症例は 1991 年 5 月より 2006 年 6 月までに本法を用

\footnotetext{
* 熊本整形外科病院 Kumamoto Orthopaedic Hospital, Kumamoto, Japan
} 


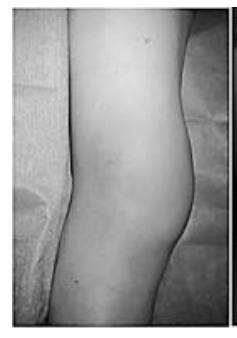

a

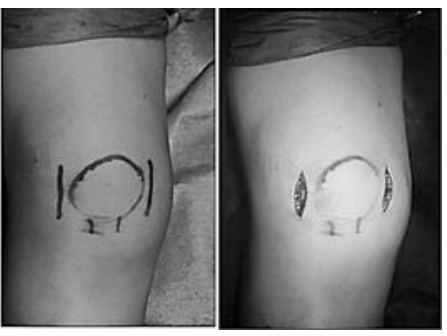

b

c
図 1 手術手技

切開洗浄後，創を開放にしたまま運動療法を開 始する.
a. 術前の状態
b. 膝蓋骨および皮切のマーキング
c. 皮切

いて治療を行った 26 例 27 膝で，性別は男性 8 例，女 性 18 例，年齢は平均 68.0 歳であった。術後経過観察 期間は最短 2 ヶ月, 最長 84 ヶ月であった.

発症前に原疾患が存在した症例は 23 例で，変形性 膝関節症が 19 例（このうち 1 例は人工膝関節置換術 後)，慢性関節リウマチが 4 例であった。合併症は糖 尿症 3 例，慢性腎不全 1 例，肝機能障害 1 例，覀性リ ンパ腫 1 例, 痛風 1 例, 膀胱瘦 1 例であった。発症原 因として明らかであった症例は 15 膝で関節内注射 13 膝，針治療 2 膝であった.

起因菌が同定された症例は 13 膝で MSSA : 8 膝, MRSA : 2 膝, ブドウ球菌属 : 2 膝, 連鎖球菌属 : 1 膝であり，その他の症例においては起因菌は同定され なかった．発症より手術までの期間は $1 \sim 19$ 日，平 均 4.7 日であった。

$$
\text { V. 結果 }
$$

1. 血液検查

術前の白血球数は $8,000 \mathrm{cu} / \mathrm{mm}$ 以下が 4 例， 8,000 $\mathrm{cu} / \mathrm{mm}$ 以上が 22 例であり, 全例, 術後正常化した. この 22 例の白血球数が正常化したのは術後 1 ～28 日 目，平均 9.5 日目であった.

術前 CRP は全例陽性（>0.5）で，22 例で陰性化 （ミ0.5）した．CRP が陰性化したのは術後 8〜55 日 目，平均 24.6 日目であった。 RAの 2 例，覀性リン パ腫の 1 例, 慢性腎不全の 1 例では最終 follow up 時も CRP は陽性であった.

術前の ESR は全例亢進していたが，最終 follow up 時も光進していた症例が 11 例存在した.

2. 創閉鎖

創は縫合を追加した 3 膝を除いた 24 膝で自然閉鎖 した．創閉鎖まで要した期間は術後 18〜42 日，平均 29.0 日であった.

3. 術後成績

Ballard らの評価に準じて評価した．ただし Good の中でも全く正常な膝機能を有するものを Excellent とし，別に評価した.

結果は Excellent が 5 膝，Good が 18 膝，Fair が 4 膝，Poor の症例はなかった．Fair の症例は 4 例とも 80 歳台と高齢であり, 関節症変化が高度で, 受傷前 より機能障害を有していたものと考えられた.

\section{4. 術後経過}

全例，一次的に炎症は鎮静化し，再発を認めていな い．また後日，関節リウマチの 1 例に人工膝関節置換 術を，変形性膝関節症の 1 例 2 膝に高位脛骨骨切り術 を行った。

\section{VI. 症例}

症例 1. 56 歳. 女性.

以前より某医にて右膝の治療を受けていた。2006 年 6 月 28 日，関節内注射を受けてから，右膝の腫脹 · 疼痛が出現した。 2006 年 6 月 30 日当院を受診した. 初診時, $38^{\circ} \mathrm{C}$ 台の発熱, 血液検査所見 (WBC 9,940, CRP 4.8, ESR $92 \mathrm{~mm} / \mathrm{hr}$ ), 及び関節の著明な腫脤 と局所熱感より化膿性膝関節炎と診断し，当日本法を 施行した。後日判明した培養の結果, 起因菌は MSSA であった。術後 5 日目より解熱傾向がみられ 術後 4 日目に WBC は正常化し, 術後 3 週に CRP は 正常化した. 創は術後 26 日目に閉鎖した. 術後 4 ケ 月の現在，右䐂痛は軽度あるものの，正座も可能であ る(図 2).

症例 2.83 歳. 男性.

2000 年 11 月頃より右膝痛があった。 2000 年 12 月 1 日より右膝痛，腫脹，局所熱感が出現した。前医に 入院し穿刺にて膿性の排液を認め, 当院紹介受診となつ た. 2000 年 12 月 4 日当院初診時， $38^{\circ} \mathrm{C}$ 台の発熱，血 液検查所見（WBC 9,370，CRP 6.2， ESR 44mm/ $\mathrm{hr}$ )，及び関節の著明な腫脹と局所熱感より化膿性膝 関節炎と診断し，直ちに本法を施行した，後日判明し た培養の結果，起因菌はStreptococcus agalactiea 
であった．高度の変形性膝関節症のため可動域訓練時 に疼痛を伴い本法を継続するのに難渋したが, 術後 1 週目より解熱傾向がみられ, 術後 1 週で WBC は正常 化し, 術後 3 週にCRP は正常化した。創は術後 35 日目に閉鎖した。膝関節の可動域は $0^{\circ} \sim 55^{\circ}$ で, Ballard らの評価では Fair であったが，膝関節の可 動域に左右差はなく発症前の状態に回復したものと考 えられた（図3）。

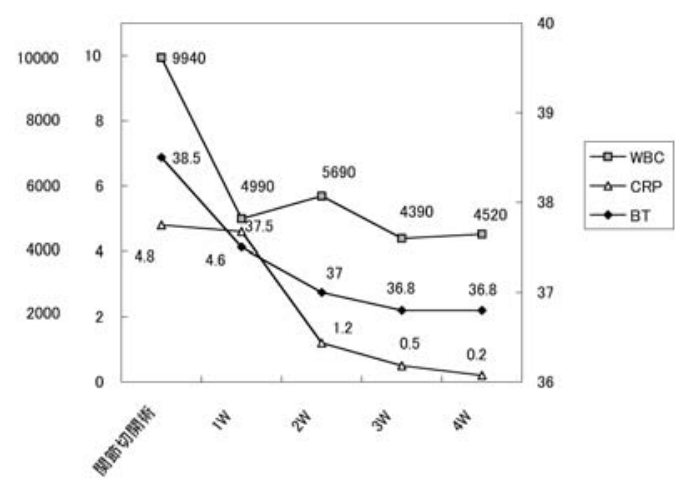

図 2 症例 1. 56 歳. 女性 起因菌は MSSA であった。術後 5 日目より解 発傾向がみられ術後 4 日目にWBC は正常化し, 術後 3 週にCRP は正常化した。創は術後 26 日目に閉鎖した。

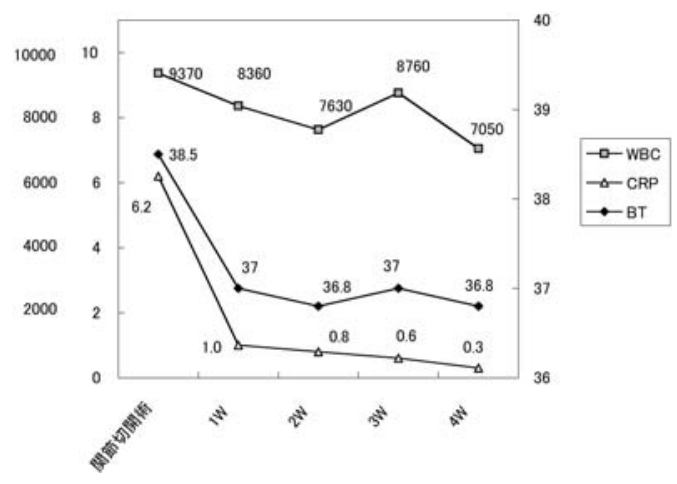

図 3 症例 2.83 歳. 男性

起因菌は Streptococcus agalactiea であった。 高度の変形性膝関節症のため可動域訓練時に疼 痛を伴い本法を継続するのに難渋したが, 術後 1 週目より解発傾向がみられ, 術後 1 週で WBC は正常化し, 術後 3 週に CRP は正常化 した．創は術後 35 日目に閉鎖した.

\section{VII. 考察}

化膿性膝関節炎の治療の原則は，局所の安静，排膿 と抗生剂投与であるとする意見が多いが，局所の安静 については早期よりの可動域訓練を推める報告もあり, 意見が分かれるところである.

排膿の方法としては，穿刺排膿法，穿刺洗浄法，持 続洗浄法，関節鏡視下洗浄（及び持続洗浄）法などが ある. 一般的には穿刺排膿法や穿刺洗浄法では大きな 壊死物質や debris の充分な排出が困難とされ成績不 良例が多く見られる．このため，大量の洗浄液で洗浄 する持続洗浄法（鏡視下法も含めて）が本邦では一般 的に行われている方法である(-6)9111).

我々も当初は，鏡視下洗浄に引き続く持続洗浄法を 用いていたが，この方法は洗浄チューブのつまりや洗 浄液のもれが頻繁に起こり，洗浄を維持するためには 二次的な処置が必要となることが多く，さらには洗浄 を途中で断念せざるを得ない場合が少なくなかつた. また，持続洗浄中に早期より可動域訓練を行うという 報告もあるが，前述の洗浄液のもれの問題もあり局所 は安静に保たざるを得ず，洗浄が長期に及ぶ場合は筋 萎縮，関節拘縮をきたした症例も経験した。 また，二 次的に滑膜切除術や，鏡視下授動術を要した症例もあ り，総じて我々の鏡視下の持続洗浄による治療成績は 決して安定したものではなかった.

これらの方法に対し関節切開に引き続く開放運動療 法は Willems ${ }^{10)}$ が 1944 年に報告し Heberling, Ballard ら ${ }^{12)}$ が追試し報告した方法であり，当時化膿 性関節炎の治療の原則とされた『局所の安静という常 識』をくつがえす方法である．本邦では田中ら ${ }^{8)}$ や岡 ら7) が追試し良好な結果を報告している，我々も第 95 回の本学会にて報告した ${ }^{3)}$. 田中らは Heberling の文 献よりの引用として本法の利点を 5 つ挙げている ${ }^{8)}$. すなわち

1）障害のある関節組織への血液供給の促進

2）充分な排膿

3）筋萎縮を防ぎ関節の炎症が消退したときに機能 を再開することが可能

4）新鮮な滑液による洗浄作用を促進

5）機能的関節の可能性の実現

である.

我々は, この他の本法の利点として 
・手術手技が簡便である.

・術後の管理が簡便である.

ことを挙げた ${ }^{3)}$. 本法の簡便さは前述した持続洗浄法 の繁雑さに比べれば明白である.

また，治療成績に関しても，我々の症例においては 全例，一次的に炎症は鎮静化しており再発を認めてお らず，その治癒率は他の方法と比べて遜色はない．

一方，関節切開法に対する否定的な意見として，関 節切開部の創閉鎖に時間がかかり関節の痏痕性拘縮を 起こす可能性があるとの考えがある，我々の症例にお いては創閉鎖まで平均 29.0 日とけっして短期間では なかったが，この時点ではほぼ退院可能な状態であり， 諸家の他の治療法の報告と比べても治療期間全体とし て長期間といえる程度ではなく，また瘢痕が原因と考 えられる拘縮は一例もなかった.

しかしながら，本法においても問題点が存在した. それは関節の変形が高度な場合である. 本法は局所の 安静はとらず，早期より関節運動を促す方法であるが， この運動そのものに疼痛を強く伴う状態であると, 疼 痛のコントロールに限界があり，また，このような症 例は殆でが高齢で本法の利点を理解できない場合があ り，運動療法がスムーズに行えず，本法に対する不満 を訴える症例も存在した

また，本疾患のいずれの治療法においてもあてはま ることであろうが, 術後成績は発症前の膝関節機能障 害の程度に大きく左右されると考えられ，高齢者で変 形性関節症が高度である症例は, 最終成績が不良であつ た.

\section{VIII. と め}

(1)化膿性膝関節炎 26 例 27 膝に対し開放運動療法を 行い全例, 一次的に炎症は鎮静化した.

(2)本法は簡便であり治癒率も極めて高 $<，$ 関節機能 も温存できる優れた方法である.

\section{参 考 文 献}

1) Ballard, C. A., et al.: The functional treatment of pyogenic arthritis of the adult knee. J. Bone Joint Surg., 57-A : 1119-1123, 1975.

2) Heberling, J.A.: A review of two hundred and one case of suppurative arthritis. J. Bone Joint Surg., $23: 917-921,1941$.

3）生田拓也ほか：化膿性膝関節炎に対する解放運動療法 の経験．整外と災外，48(2)：446-449，1999.

4）伊藤 靖ほか：化膿性膝関節炎に対する鏡視下治療の 経験。整形外科, 44:67-70, 1993.

5）亀山 修ほか：化膿性膝関節炎に対する鏡視下治療の 経験。整・災外，31：195-199，1988.

6）川嶌真人ほか：関節感染症に対する局所持続法洗浄療 法. 整・災外, $23: 865-874,1980$.

7）岡 義春ほか：化膿性膝関節炎に対する開放運動療法. 整・災外，33:1627-1630, 1990 .

8）田中信陽ほか：化膿性膝関節炎に対する機能的治療法 の経験. 整形外科, $33: 324-328,1982$

9) 鳥巣岳彦：化膿性膝関節炎。関節外科, 3:449-454, 1984.

10) Willems, C.: Treatment of purulent arthritis by wide arthrotomy followed by immediate active mobilization. Surg. Gynecol. Obstet., $28: 546-554,1919$.

11）吉田孝太郎ほか：化膿性膝関節炎の観血的療法と後療 法について. 整形外科, $40: 604-611,1989$. 